\title{
Benefits of University-Industry Cooperation for Innovations of Sustainable Biological Control
}

\author{
Daniela Althoff Philippi', Emerson Antonio Maccari², Claudia Brito Silva Cirani ${ }^{3}$
}

\begin{abstract}
This study aims to identify the benefits of technological cooperation between the College of Agriculture Luiz de Queiroz - University of São Paulo (Esalq/USP) and the start-up Bug, a company that operates in the biological control of pests as a sustainable alternative to traditional methods. This research was based on a case study regarding a technological cooperation, which resulted in sustainable innovation involving a biological control of pests through the use of a parasite wasp that naturally parasitize the sugarcane borer's eggs, preventing the growth of caterpillars in field crops. The technological cooperation led the company to extend its cooperation to other educational and research institutions.
\end{abstract}

Keywords: technological cooperation; university; industry; benefits; biological control; sustainable innovation.

\footnotetext{
'Universidade Federal de Mato Grosso do Sul (UFMS), ${ }^{2,3}$ Universidade Nove de Julho (UNINOVE), Av. Francisco Matarazzo, 6 I2, 2 andar Torre C, Água Branca, 0500 I- 100, São Paulo - SP, Brazil. E-mail: I daniela.philippi@ufms.br (corresponding author). 


\section{Introduction}

Technological cooperation between university and industry can bring benefits to the parties involved and the society. The study on cooperative agreements between research and business institutions, notably in terms of structure and management, may contribute to the development of innovative management models, supporting the consequent economic and technological growth of developing countries (Costa, Porto and Feldhaus, 2010). Furthermore, in those countries, typically, small and medium enterprises do not have structured Research and Development (R\&D) activities, making necessary the search of external sources of innovation, which can be achieved by cooperation with the university (Benedetti and Torkomian, 20I0).

Studies pointed out that technological cooperation between university and industry can benefit the parties involved as well as the society (Closs and Ferreira, 2012; Di Gregorio and Shane, 2003; Zucker and Darby, 200I).

Many entrepreneurs still believe that investments in sustainable businesses do not provide return, but some studies Nidumolu, Prahalad and Rangaswami (2009) have shown that only enterprises targeted at sustainability will have a competitive advantage.

In Brazil, cooperation between university and industry is recent and few studies have been conducted on this subject. In addition, few studies, nationally and internationally, focus on start-ups created from academic research that maintain cooperative arrangements based on sustainable innovation. However, Bug is a start-up in Brazil, founded from research developed at College of Agriculture Luiz de Queiroz University of São Paulo (Esalq/USP), and is internationally recognized as the most innovative Brazilian enterprise by Fast Company (Lidsky, 2012) and one of the most innovative companies in the world by the World Economic Forum (WEF) (WEF, 2014), due to its sustainable innovation for pest biological control.

The objective of this study was to identify the benefits of technological cooperation between Esalq/USP and Bug.

Firstly, we present a literature review about cooperation between university and industry, the National Systems of Innovation (NSI), sustainable innovation and possible benefits from cooperative between university and industry. Secondly, we conduct the methodological procedures to explain the qualitative research. Thirdly, we present the results where the main innovation of Bug in the pest biological control is characterized as sustainable innovation, the benefits of the cooperation with Esalq/USP, their relation with other studies and new evidence of this specific case study.

\section{Literature review}

Cooperation between the university and industry began to receive attention from academic studies mainly in the 1960s, with the studies of Sábato and Botana (1968) in Latin America. The authors evaluated the interaction between the university, industry and the government as a means of boosting growth of developing countries. The studies resulted in the "Sábato Triangle Model" where corners are occupied by the government, the productive structure (business or industry) and the scientific and technological infrastructure of a country. The model indicates that, in addition to a robust scientific and technological infrastructure, it is necessary to transfer research results to the production structure with funds from the government and its regulatory power.

In the 1980s, Freeman and Lundvall (Motta and Albuquerque, 2004) presented the concept of NSI. NSI emphasizes the interaction between its agents (organizations and institutions, such as universities and research institutes, the government and industry) to attain technological development (Freeman, 1995). NSI also plays an important role in this process because of the network of information for a business to implement innovations (Lundvall, 1992).

In the mid-1990s, the Sábato Triangle Model, linked to the NSI concept evolved, and the Triple Helix Model was created by Henry Etzkowitz, based on observations of the performance of the Massachusetts Institute of Technology (MIT) and its relationship with the conglomerate of high-tech enterprises in its surroundings (Valente, 2010). The objectives and structure of the Triple Helix Model are basically the same as those of the SábatoTriangle Model, but the players - university, government and industry - have an interaction with different understandings and attitudes and share responsibilities in scientific and technological development without hierarchy (Etzkowitz and Leydesdorff, 2000). For Henry Etzkowitz, the interaction between the three players allowed for the creation of a system of sustainable and durable innovation in modern economies (Valente, 2010). Thus, models such as the Sábato Triangle and the Triple Helix and the studies on NSI related to their establishment in several countries underscore the importance of the interactions between the university, government and industry.

The interaction between the university and research institutes with enterprises has been increasingly emphasized as a driver for scientific advances and, consequently, economic and social development for developing countries. Technological advances make the market increasingly competitive and lead enterprises to excel, which can be achieved by innovation. Innovation through cooperation between the university and industry has become an alternative for companies searching to remain competitive, contributing to the country's competitiveness as a whole. 
Cooperation between university and industry may involve technology transfer (TT). TT is the transfer of knowledge generated by the university to an enterprise, enabling it to innovate and expand their technological capabilities, ensuring competitive advantage in the marketplace (Closs and Ferreira, 20I2).

TT can be classified as formal and informal. Formal TT refers to the transfer of research results as a patent or a license to use the technology, including property rights, while informal TT does not include such expectation (Grimpe and Fier, 2010). Informal TT can be a contact between academics and business members through conferences, joint publications, academic consultancy and other informal contact, conversations and meetings (Grimpe and Fier, 20l0), besides the technical assistance and joint research (Bradley, Hayter and Link, 2013). Costa, Porto and Feldhaus (2010) noted that the growth of the cooperative agreements between research institutions and business institutions represents a new trend in society, and the study on these arrangements, notably its structure and its management, may contribute to the development of innovative management models, supporting consequent economic and technological growth in developing countries.

The transfer of intellectual property has also been studied through the creation of new businesses (start-ups) by identifying the reasons some universities generate more start-ups than others to transfer their intellectual property such as the performance in emerging areas of the economy and profit participation by the information owner (Di Gregorio and Shane, 2003).
A start-up can be considered a university spin-off, that is, a company created by students and postdoctoral researchers based on research conducted at the universities (Bercovitz and Feldmann, 2006), and can be characterized as formal or informal TT.

Studies that link the university success and its researchers to the success of projects comprise: (I) gathering the necessary resources to found a company to explore uncertain new technology is easier when the university's status enhances the entrepreneur's credibility ( $\mathrm{Di}$ Gregorio and Shane, 2003); (2) companies that have cooperative relations with renowned scientists from universities have positive impacts on productivity, product development and market integration (Zucker and Darby, 200I); (3) the presence of experts and engineers of a particular field affects positively the activity of spin-offs and their capacity to create radical innovations (O'Shea et. al., 2005).

Few studies have been reported in the international and national literature regarding agreements between university and business institutions and innovation or sustainable organizations, as well as studies that investigate sustainable start-ups.

Many entrepreneurs believe that investments in sustainable businesses do not provide return. On the other hand, studies show that companies that pursue new technologies can originate start-ups with capacity to challenge conventional criteria, reduce costs and increase revenue. Studies (Nidumolu, Prahalad and Rangaswami, 2009) predict that in the future only companies that focus on sustainability will have a competitive advantage. Those authors present stages in which smart companies anticipate the introduction of SD plan and anticipate challenges through innovation focused on sustainable development (SD) (Table I).

\begin{tabular}{|l|l|}
\hline Stages & Explanation \\
\hline $\begin{array}{l}\text { (I) perceive challenges as an opportuni- } \\
\text { ty, concerning obligations, laws, specific } \\
\text { standards }\end{array}$ & $\begin{array}{l}\text { anticipating or being a pioneer can create opportunities with innovation, gain } \\
\text { advantage by pioneering, opening markets, achieving technological domain and } \\
\text { can even create new products and/or services and become a supplier }\end{array}$ \\
\hline (2) create sustainable value chains & $\begin{array}{l}\text { having supply chain involved in the SD concept that could also open way for } \\
\text { innovation }\end{array}$ \\
\hline $\begin{array}{l}\text { (3) design sustainable products and } \\
\text { services }\end{array}$ & $\begin{array}{l}\text { taking into account in their projects for products and process the social, } \\
\text { economic and environmental dimensions of SD }\end{array}$ \\
\hline (4) develop new business models & $\begin{array}{l}\text { developing new forms of delivering, distributing and aggregating value, which } \\
\text { change the basis of competition }\end{array}$ \\
\hline (5) create new platforms for action & relating them to SD to remain ahead of competition \\
\hline
\end{tabular}

Table I: Stages of smart companies that anticipate the introduction of SD Source:Adapted from Nidumolu, Prahalad and Rangaswami (2009)

ISSN: 07I 8-2724. (http://www.jotmi.org) 
In addition, Kanter (1999) presents social innovation and start-ups as alternatives that go beyond the former corporate models, incapable of creating sustainable change models. Therefore, the start-ups or spin-offs, arising from academic research, can add sustainable innovation to their business as a result of the cooperation process between research institutions and business institutions. Currently, universities that work on agricultural subjects have been increasingly adding the concern with SD into their activities. Sustainable innovation requires a new thinking about innovation that contributes to the achievement of SD. Barbieri et. al. (2010) claim that SD is the introduction of products, production processes, operating methods or business, new or significantly improved for the organization and that considers economic, social and environmental benefits as relevant alternatives.

Sustainability has three main dimensions: economic, social and environmental. In the business environment, the term "the triple bottom line" is used to show the importance of achieving sustainability, which implies that enterprises have to expand their traditional economic focus by including the environmental and social dimensions in order to create a more sustainable business (UNEP, 2013).

Thus, we observe the emergence of production activities in terms of innovation and sustainability, based on the limits and serious predictions. The effort must involve NSI and the Triple Helix Model all together.

\section{Methodological procedures}

The study was regarded as qualitative and as a case study, because it is an empirical and in-depth study of relationships, processes and phenomena that were based, predominantly, on testimony and information of respondents (Minayo et. al. 1994, Flick, 2004, Eisenhardt, 1989, Yin, 200I). The study was also exploratory because it aimed at familiarization with the phenomenon or a new perception about it and the discovery of new ideas (Babbie, 1998; Eisenhardt, 1989).

Data were collected based on secondary (literature and documents) and primary sources (interviews) from Esalq/ USP and an enterprise.
We investigated the benefits of creation and history of startups in innovation processes, mainly the relationship between Esalq/USP and the enterprise. We also identified benefits of its implementation regarding SD. As the research was about cooperation between the university and industry, we selected by an intentional and non-probabilistic sample (Selltiz, Wrightsman and Cook, 1974) the Professor, Researcher and Coordinator of the Insect Biology Laboratory of Esalq/ USP, where the research was conducted and that keeps a relationship with the company and one of Bug founders.

The interviews were semi-structured and the organizational documents were consulted on the company's website, and the bibliographic sources were obtained mainly from the Fast Company Magazine and the World Economic Forum (Lidsky, 20I2; WEF, 20I4). After transcribing the interviews, the data collected was grouped into different sources to identify the creation process of the start-up, its main innovation and its relation to SD. The most significant contents of the interviews, documents and references for a systematic analysis were identified as the research objective. The data of primary and secondary sources was triangulated and analyzed together (Flick, 2004).

\section{Results}

Despite the benefits that technological cooperation between university and industry provides to both institutions and society, mainly when there is a link with start-ups and sustainable innovation, research and practice of these concepts together have not been thoroughly explored.

Thus, this paper aimed to identify the benefits of technological cooperation between Esalq/USP and a start-up in the agricultural sector that originated from this cooperation and operates with sustainable innovations.

Because of the few studies on technological cooperation related to sustainable innovation, this study presents a case study of a start-up that has operated for 12 years in pest biological control as a sustainable alternative.

The company founders were graduate students at Esalq/ USP and used to work at the Laboratory of Insect Biology of the Entomology and Acarology Department, where they developed research on biological control of insect pests (founder and partner of Bug and a Professor from Esalq/USP).

The company can be considered a start-up and a spin-off (Bercovitz and Feldmann, 2006) because scholars (who were founders and partners of the enterprise) created it based on their research during graduate school at Esalq/USP.

ISSN: 07 I8-2724. (http://www.jotmi.org) 
Esalq/USP has, throughout its 105 years of existence, contributed decisively to the technological advancement of Brazilian agriculture by training human resources and generating results through research in Agricultural Sciences. Currently, the institution offers specialization courses and hosts the National Biofuels Center, The Rural Producer Home and an Agro and Zootechnical Business Incubator (ESALQ TEC) (USP/ESALQ, 20/3). Distributed in 13 departments with highly qualified faculty, Research and Extension consists of 250 professors who develop more than 500 research projects in 120 laboratories on campus, generating knowledge, processes and products to the society (USP/ESALQ, 20I3).

Initially, the company operated in the biological control of the major sugarcane pest, the sugarcane borere, and expanded the pest control to other cultures, such as soybean and others. Today, in addition to maintaining partnership with Esalq/USP, the enterprise has expanded cooperation with universities and with the Brazilian Agricultural Research Corporation (EMBRAPA) (founder and partner of Bug).

In the company's history, technological cooperation has been crucial for the development of sustainable innovations earning it recognition in the national and international scenarios. The enterprise was nominated by Fast Company Magazine as the most innovative company in Brazil and by the World Economic Forum as one of the most innovative companies in the world for the revolutionary use of wasps in pest biological control in agriculture (Lidsky, 20I2;WEF, 20I4).
The greater innovation of the company was the use of a wasp (trichogramma) that parasites on the eggs of insect pests, preventing the formation of caterpillars in crops (soybean and sugarcane). This innovation provided to the enterprise a great differentiation over its market competitors, because this method is more sustainable for pest control than the traditional method of using pesticides and biological methods adopted by other enterprises - notably for the use of wasps before the larvae become caterpillars, which makes the process more productive (founder and partner of Bug). The innovation is unique because the larva does not evolve as it does in other methods for biological control. Compared to pesticide use, the innovation requires a single application rather than three, as it currently occurs in many crops due to the increase of pesticide-resistant insect populations due to successive use of chemical products (founder and partner of Bug). To this economic efficiency can be added the environmental and social performance. The innovation developed by the enterprise led to a major market change, because it is highly competitive leading in its performance and because other companies to develop similar technologies, in addition to being a sustainable alternative.

The cooperation between the company and Esalq/USP has led to a concern with SD due to the knowledge brought by the founders. This concern was evident in the interviews. Human population growth and necessary support to agriculture to provide food considering the "growth limits" drive the search for greater sustainability in agriculture. In terms of SD scope (Barbieri et. al., 2010), the benefits of the company's innovation in the research, based on the interviews are presented in Table 2:

\begin{tabular}{|l|l|}
\hline Dimensions of SD & Benefits of Bug's innovation \\
\hline Environmental & $\begin{array}{l}\text { Prevents local contamination, which usually occurs with the spray of the pesticides (infecting } \\
\text { people and other areas) and also in terms of the biological balance with the release of parasit- } \\
\text { oids }\end{array}$ \\
\hline Social & Provides organic food, handling (employees), avoiding contamination and poisoning \\
\hline Economic & $\begin{array}{l}\text { The biological control is usually cheaper than pesticide use and, nowadays, due to resistance } \\
\text { of pests, pesticides are usually applied three times more than before, therefore, the biological } \\
\text { control is less costly to growers }\end{array}$ \\
\hline
\end{tabular}

Table 2: Benefits of Bug's innovation that characterize it as a sustainable innovation Source:Authors based on primary and secondary data 
Thus, the technology developed by the company offers fewer problems to the environment, reducing risks to people involved in the process and lowering costs caused by of pesticide applications. Regarding SD benefits, the company proves that a business can be sustainable and profitable (Nidumolu, Prahalad and Rangaswami, 2009) and that sustainability can lead to competitive advantages and radical innovations, placing the company as "smart company".

Bug is considered a company which anticipates the introduction of SD - a smart company -, by treating sustainability as a key driver of innovation and following the stages mentioned in the literature (Nidumolu, Prahalad and Rangaswami, 2009). However, its founder and partner stated that there is no direct influence of laws in the company's innovation process. The stages that the company underwent are specified in Table 3.
The constant search for innovations through its cooperation ensures the company the condition of a smart and featured company. Its inception was already based on this concept with the high qualifications of its founders and partners and a direct connection with a renowned researcher in the research field and with the entire cooperation and support of the most prestigious institution in studies on agricultural sciences in Latin America - Esalq/USP.

\begin{tabular}{|l|l|}
\hline Stages & How? \\
\hline (I) Creating opportunities with innovation & By conquering competitive advantage with its pioneering \\
\hline (2) Creating a sustainable value chain & $\begin{array}{l}\text { By starting with its inception at Esalq/USP and with the } \\
\text { cooperation with other institutions to develop basic re- } \\
\text { search and through the development of packaging and the } \\
\text { different commitment employed by agents }\end{array}$ \\
\hline (3) Conceiving and creating sustainable products & By considering the scope of SD \\
\hline (4) Developing new business models & $\begin{array}{l}\text { Through the way the company was started and the exten- } \\
\text { sion of its cooperation, the way of distributing products, } \\
\text { that is, the enterprise does not focus only on the product } \\
\text { itself, but on alternatives to increase its demand through } \\
\text { the development of new packaging to facilitate the trans- } \\
\text { port by agents }\end{array}$ \\
\hline (5) Creating new platforms for actions & $\begin{array}{l}\text { By searching for basic research, extending the cooperation } \\
\text { to other institutions, besides Esalq/USP, with the creation } \\
\text { of packaging , the continuous search for improvement, } \\
\text { hiring a researcher/professor of a prestigious university } \\
\text { to integrate its Research and Development (R\&D) team, } \\
\text { facilitating the communication with the university) }\end{array}$ \\
\hline
\end{tabular}

Table 3: Stages followed by Bug to become a smart company by treating sustainability as a key driver of innovation Source:Authors based on primary data 
There are many benefits from the cooperation between Esalq/USP and Bug and they confirm previous studies, as shown in the following evidence.

First, it is understood that the growing appreciation and development of the biotechnology, along with the expertise of the enterprise's founders and the consolidation of the academic research at Esalq/USP, which led to the creation of the company and its sustainable innovations.According to $\mathrm{Di}$ Gregorio and Shane (2003), some universities generate more start-ups than others do, which is attributed to the emerging areas of the economy where they operate. Mendes,AmorimBorher and Lage (2013) state that the biotechnology industry has played a special role in technological innovation in many countries. Similar to this case study, where biotechnology uses living organisms (insects) in pest control adopting the concept of SD that is constantly increasing in agriculture for food production.

The cooperation also stimulated the participation in the Innovative Research in Small Business Program (PIPE) and in the Support for Research in Companies Program (PAPPE), granting the enterprise the support from the Foundation for the Research Support of the São Paulo State (FAPESP) to be established and to search for innovations.

The founder and partner of Bug participated in various phases of PIPE, which helped to support the enterprise obtain larger amounts of funds through FAPESP and Esalq/ USP, with the approval of technical and financial assessments. This mechanism facilitates the creation of the enterprise and corroborates other studies (Di Gregorio and Shane, 2003) in the aspects that lead some universities to generate more start-ups than others.

The formalization with Esalq/USP was performed with projects sponsored by FAPESP, through the Professor in charge of the project who provided academic support (founder and partner of Bug). The cooperation with Esalq/ USP granted access to resources for the company's innovative activities, since, according to founder and partner of Bug, the project required cooperation with researchers and allowed the company to use laboratories at the university.
Another benefit generated by the cooperation was the use of the physical space of Esalq/USP during the initial phase of the enterprise's activities (founder and partner of Bug). During the first year and a half, the company used the laboratory and in the next five years, it used the physical space of the technology incubator that, at the time, was vacant. The equipment was purchased through projects sponsored by FAPESP and was initially allocated to the university. After five years, with the consolidation of the company, all the equipment became an asset of the company (founder and partner of Bug).

The expertise of the researcher and founder of Bug, who is also the coordinator of the laboratory where the research was developed as well as the reputation of a renowned university such as Esalq/USP were also mentioned in the interviews as benefits of the cooperation for the insertion of the company into market and its current performance. In addition, these aspects contributed to the success of its products. This corroborates findings of previous studies that companies that have a cooperation with renowned scientists of universities have positive effects of their products and insertion into the market (Zucker and Darby, 200I). The presence of renowned scientists positively affects the activity of spin-offs leading to the creation of radical innovations (O'Shea et. al., 2005), which was proved by the capacity of the enterprise's founders to create innovative technology. Table 4 shows the benefits of cooperation between Esalq/ USP and the start-up Bug confirming previous studies. 


\begin{tabular}{|l|l|}
\hline $\begin{array}{l}\text { Possible benefits from cooperation } \\
\text { between the university and industry } \\
\text { according to the literature }\end{array}$ & $\begin{array}{l}\text { Benefits of Esalq/USP and Bug cooperation case study (empirical } \\
\text { evidences) }\end{array}$ \\
\hline $\begin{array}{l}\text { Provides easier conditions to get technical } \\
\text { and financial assessments approved, facili- } \\
\text { tating the foundation and the establishment } \\
\text { of start-ups (Di Gregorio and Shane, 2003) }\end{array}$ & $\begin{array}{l}\text { Participation in programs such as PIPE and PAPPE allowing Bug to get sup- } \\
\text { port from FAPESP, to be established and to search for innovations } \\
\text { Use of physical space at Esalq/USP during the initial years of Bug's activities }\end{array}$ \\
\hline $\begin{array}{l}\text { Relationship with renowned scientists of } \\
\text { renowned universities provides positive } \\
\text { effects of products and insertion into the } \\
\text { market as well as the creation of radical in- } \\
\text { novations (Zucker and Darby, 200I; O'Shea } \\
\text { et. al., 2005) }\end{array}$ & $\begin{array}{l}\text { The expertise of Esalq/USP researchers and the University reputation pro- } \\
\text { vide Bug market entry, current performance of the success of its products, } \\
\text { to act (as a spin-off) with the creation of radical innovations }\end{array}$ \\
\hline $\begin{array}{l}\text { If the university works in emerging areas of } \\
\text { the economy, there is an increased possibil- } \\
\text { ity to generate more startups than others } \\
\text { (Di Gregorio and Shane, 2003) }\end{array}$ & $\begin{array}{l}\text { Bug is a start-up generated from research at Esalq/USP, which works mainly } \\
\text { on agriculture for food production, and especially at its Department of } \\
\text { Entomology, where biological control of pests is an important field of study } \\
\text { and considered an emerging field of economy }\end{array}$ \\
\hline
\end{tabular}

Table 4: Esalq/USP and main cooperation benefits for main sustainable biological control innovations Source:Authors based on primary data 
Moreover, benefits of cooperation between Esalq/USP and Bug, another factor evidenced in the interviewees was the feeling of gratitude and partnership between the company and Esalq/USP that, supported by FAPESP and according to the founder and partner of the company, has granted participation of the company in events abroad allowing to show Brazilian technology for biological pest control and also to create opportunities to meet with potential clients. Nowadays Bug has expanded its cooperation with other institutions - another university and a research institute - besides the cooperation with Esalq/USP. Bug transforms their basic research into something that can be produced at large scale.

Figure I summarizes the main benefits of cooperation between Esalq/USP and Bug.
Thus, the company is an example of a consolidation of a new business model based on cooperation with universities and research institutes, allowing production in large scale reducing costs.

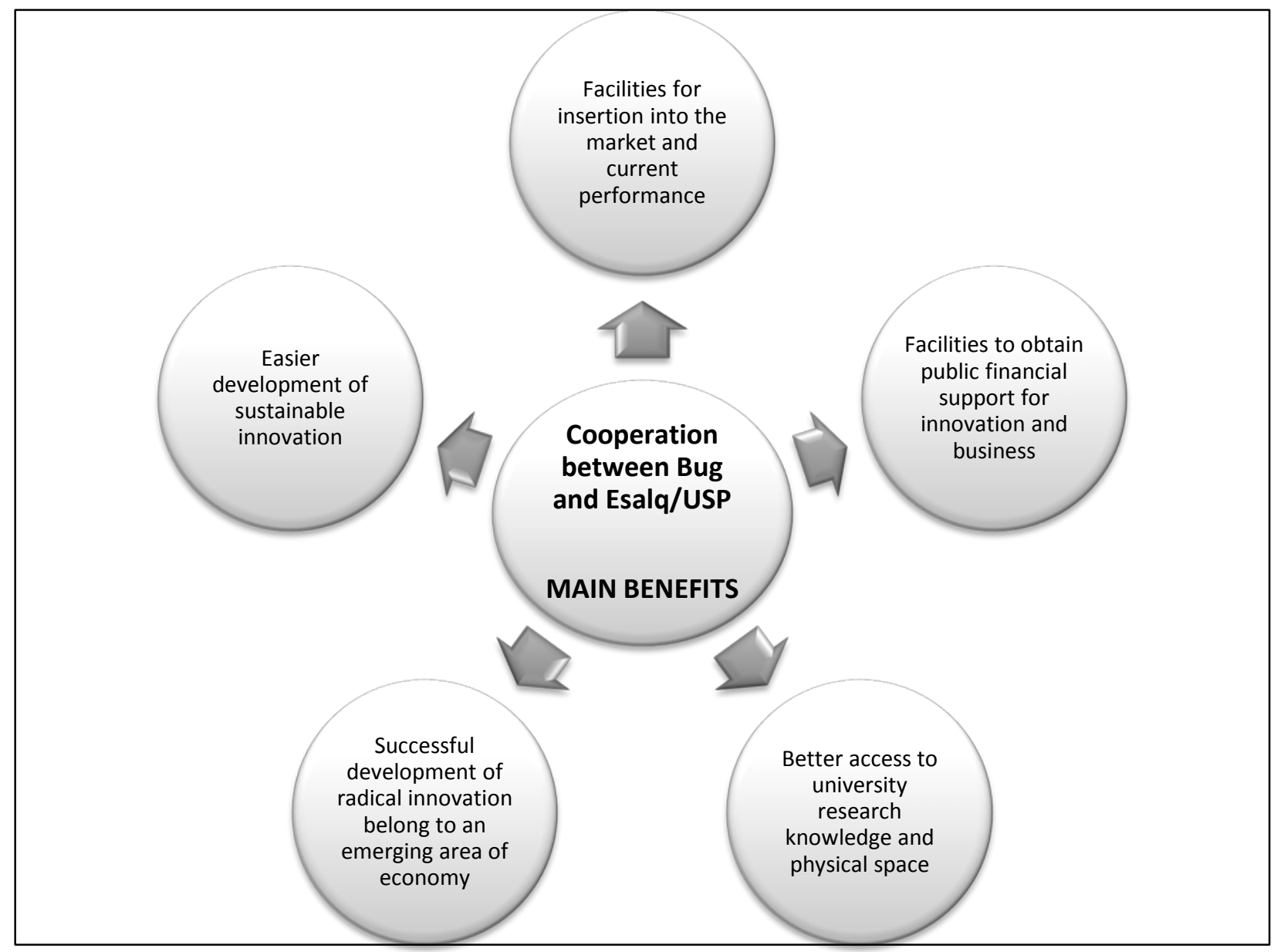

Figure I: Main benefits of cooperation between Esalq/USP and Bug Source:Authors based on primary and secondary data

ISSN: 07 I8-2724. (http://www.jotmi.org) 


\section{Conclusions}

Start-ups, as the one investigated in this research, are companies that can be originated from academic research (spin-offs). They strengthen the cooperation process with universities and research institutes and provide a new dynamic to SD.

The company's innovations created from research in educational and research institutions, particularly at Esalq/ USP, greatly reduce the negative impacts to the environment and favor a number of consumers by turning academic research into viable products for commercialization, by processing and adapting them into the "production scales" and finally into innovation.

Few studies have been conducted on start-ups and spin-offs with the same purpose of the case study presented here and, some authors claim that there are divergences in the literature regarding the company reality. Therefore, further studies are suggested to better understand the innovations from cooperative agreements between research institutions and the industry related to the paradigm of SD.

We hope that our results expand the studies on cooperative interactions, and because it is a case of excellence related to $S D$, we expect that our results will inspire organizations and universities to practice cooperation allied to sustainable innovation. The case study shows how the university can contribute more effectively to the society, since the basic research that remains within the "university walls" is "the basis" for the company's successful innovations, which have significantly reflected to SD with potential to contribute even more in the future.

After 12 years of existence, Bug has kept its partnerships with Esalq/USP and it has extended its cooperation to other universities and a research institute, which has earned its leading position in the country in the biological control of pests in soybean and sugarcane, proving that besides the benefits, technological cooperation is a strategy adopted by Bug.
The main benefits observed are related to the business and society as a whole, but another study could be conducted on the university benefits from the cooperation with Bug. Also, further studies could check the factors analyzed here involving Bug and Esalq/USP to indicate whether the behavior differs from those identified in cooperation with other institutions (universities and/or research institutions). Studies that address all the variables of this research are also proposed, given that the literature addresses many of these variables separately. Success stories similar to those presented here need to be further investigated to contribute to the theory and practice of other organizations.

The company addressed in this study is closely linked to the university since its inception as a start-up and spin-off, therefore, its history can be extended to other universities and research institutes, considerably increasing the possibility of more and successful innovations.

This study also highlights that the government, represented by FAPESP in this case study, plays an essential role in encouraging the achievement of technological cooperation and creating spin-offs.Therefore, efforts for the consolidation of technological cooperation can be more successful and facilitate the attainment of expected and potential benefits if they are driven by NSI and Triple Helix Model. 


\section{References}

BABBIE, E.(1998).The practice of social research.Wadsworth Publishing Company, Belmont.

BARBIERI, J. C., Vasconcelos, I. F. G. de, Andreassi, T., Vasconcelos, F. C. de. (20I0). Inovação e sustentabilidade: novos modelos e proposições. Revista de Administração de Empresas, 50(2), I 146-I54.

BENEDETTI, M. H.,Torkomian, A. L. V.(20I0). Uma análise da influência da cooperação Universidade-Empresa sobre a inovação tecnológica. Gestão \& Produção. I7(4), I45-I58.

BERCOVITZ, J., Feldmann, M. (2006). Entrepreneurial universities and technology transfer:a conceptual framework for understanding knowledge-based economic development. Journal of Technology Transfer, 3 I (I), I75-I88.

BRADLEY, S. R., Hayter, C. S., Link, A. N. (20I3). Models and methods of university technology transfer. The working papers of the Department of Economics at the University of North Carolina at Greensboro, 13(10). http://bae.uncg. edu/econ/research/working-papers/ [Accessed November $15,2013]$

CLOSS, L. Q., Ferreira, G. C. (20/2). A transferência de tecnologia universidade-empresa no contexto brasileiro: uma revisão de estudos científicos publicados entre os anos 2005 e 2009. Gestão \& Produção, 19(2), 419-432.

COSTA, P. R. da, Porto, G. S., Feldhaus, D. (2010). Gestão da cooperação empresa-universidade: o caso de uma multinacional brasileira. Revista de Administração Contemporânea, I4(I), 100-121.

DI GREGORIO, D., Shane, S. (2003). Why do some universities generate more start-ups than others? Research Policy, 32(2), 209-227.

EISENHARDT, K. M. (1989). Building theories from case study research.Academy of Management Review, I4(4), 532 550.

ETZKOWITZ, H., Leydesdorff, L. (2000). The dynamics of innovation: from national systems and mode 2 to a triple helix of university-industry-government relations. Research Policy, 29(2), 109-23.

FLICK, U. (2004). Uma introdução à pesquisa qualitativa. Bookman, Porto Alegre.
FREEMAN, C. (1995). The national system of innovation in historical perspective. Cambridge Journal of Economics, 19(I), 5-24.

GRIMPE, C., Fier, H. (20I0). Informal university technology transfer: a comparison between the United States and Germany. The Journal of Technology Transfer, 35(6), 637-650.

KANTER, R.M. (1999). From spare change to real change: the social sector as beta site for business innovation. Harvard Business Review, 77(3), I22-132.

LIDSKY, D. (20/2). Most innovative companies. 33 Bug agentes biológicos. for breeding a natural alternative to harmful agricultural pesticides. Fast Company. http://www. fastcompany.com//3017467/most-innovative-companies20I2/33bug-agentes-biologicos. [Accessed August I5, 20I3].

LUNDVALL, B. A. (1992). National systems of innovation: towards a theory of innovation and interactive learning. Pinter Publishers, London.

MENDES, L., Amorim-Borher, B., Lage, C. (2013). Patent applications on representative sectors of biotechnology in Brazil: an analysis of the last decade. Journal of Technology and Management Innovation, 8(4), 9I- 102.

MINAYO, M. C. de S., Deslandes, S. F., Neto, O. C., Gomes, R. (1994). Pesquisa social: teoria, método e criatividade. Vozes, Petrópolis.

MOTTA E., Albuquerque, E. da (2004). Idéias fundadoras. Revista Brasileira de Inovação, 3(I), 9-13.

NIDUMOLU, R, Prahalad, C. K. ,Rangaswami, M. R. (2009). Why sustainability is now the key driver of innovation. Harvard Business Review, 87(9), 56-94.

O'SHEA, R. P., Allen, T. J.; Chevalier, A., Roche, F. (2005). Entrepreneurial orientation, technology transfer and spinoff performance of U.S. universities. Research Policy, 34 (7), 994- 1009.

SÁBATO, J., Botana, N. (1968). La ciência y la tecnologia en el futuro de América Latina. Revista de La Integración, I (3), I5-36.

SELLTIZ, C.,Wrightsman, L.S., Cook, S.W. (1974). Métodos de pesquisa nas relações sociais. Ed. Pedagógica e Universitária Ltda., São Paulo. 
UNEP-UNITED NATIONS ENVIRONMENT PROGRAMME (2007). Annual Report 2007. http://www. unep.org/PDF/AnnualReport/2007/AnnualReport2007_en_ web.pdf. [Accessed November, 8, 2013].

UNIVERSIDADE DE SÃO PAULO (2013). Escola Superior de Agricultura Luiz de Queiroz. http://www.esalq.usp.br/. Accessed March 4, 2013.

VALENTE, L. (2010). Hélice tríplice: metáfora dos anos 90 descreve bem o mais sustentável modelo de sistema de inovação. Conhecimento \& Inovação, 6(I), 6-9.

WEF-WORLD ECONOMIC FORUM (2014). Reports: technology pioneers. http://reports.weforum.org/ technology-pioneers-20 I4/company-profiles/bug-agentesbiologicos/ [Accessed August 15, 2013].

YIN, R. K. (200I). Estudo de caso: planejamento e métodos. Bookman, Porto Alegre.

ZUCKER, L. G., Darby, M. R. (200I). Capturing technological opportunity via Japan's star scientists: evidence from Japanese firms' biotech patents and products. The Journal of Technology Transfer, 26(I-2), 37-58. 